\title{
The effect of feeding soyabeans with different particle size on the content of conjugated linoleic acid and other fatty acids of longissimus dorsi muscle, backfat and liver of beef cattle*
}

\author{
W. Sun ${ }^{1}$, G.Y. Zhao ${ }^{1,3}$, E.L. Song ${ }^{2}$, F.C. Wan ${ }^{2}$, X.M. Liü ${ }^{2}$ and W.J. Ma ${ }^{1}$ \\ ${ }^{1}$ State Key Laboratory of Animal Nutrition, College of Animal Science and Technology, \\ China Agricultural University \\ Beijing 100193, P.R. China \\ ${ }^{2}$ Institute of Animal Science, Shandong Academy of Agricultural Sciences \\ Jinan 250100, P.R. China
}

(Received 21 January 2009; revised version 10 February 2009; accepted 24 June 2009)

\begin{abstract}
Fourteen 24-month-old castrated crossbred bulls (Luxi $\times$ Limousin) weighing $504.7 \pm 15.6 \mathrm{~kg}$ were used to study the effect of feeding soyabeans with different particle size on fatty acid composition of longissimus dorsi muscle, backfat and liver. The cattle were divided into three groups with 5, 5 and 4 bulls in groups 1, 2 and 3, respectively. The cattle were fed diets containing $69.4 \mathrm{~kg}$ dry matter finely ground roasted soyabeans, coarsely ground roasted soyabeans, or roasted whole soyabeans as Treatments 1, 2 and 3, respectively. The cattle were slaughtered at the end of the 28-day experiment and longissimus dorsi muscle, backfat and liver were sampled for fatty acid analysis.

It was found that the total conjugated linoleic acid (CLA) content of liver in Treatment 3 was significantly higher than in Treatments 1 and $2(\mathrm{P}<0.05)$. The total CLA content of backfat of Treatment 3 tended to be higher than that of Treatments 1 and 2, and the total CLA content of Treatment 2 tended to be higher than that in Treatments 1 and 3, but the differences did not reach statistical significance $(\mathrm{P}>0.05)$. It is concluded that the supplementation of roasted whole soyabeans to fattening beef cattle was feasible for increasing the total CLA content of backfat and liver in beef cattle. Higher supplementation levels of soyabeans in the diet of beef cattle and longer feeding experiments to validate the effect are needed.
\end{abstract}

\footnotetext{
* Supported by Projects "Studies on the Technical System for the Production of Functional Beef", 2006BAD14B07-5-3, and "Optimum Feeds and Feeding Techniques for High Quality Beef Production in the Western Region", nyhyzx07-035-05

${ }^{3}$ Corresponding author: e-mail: zhaogy@cau.edu.cn
} 
KEY WORDS: soyabeans, conjugated linoleic acid, longissimus dorsi muscle, backfat, liver, beef cattle

\section{INTRODUCTION}

In recent years, people have become increasingly interested in healthy foods, especially in health-promoting products. The adverse effects of total fat and saturated fatty acid contents of beef became an incentive for producing beef containing higher proportions of conjugated linoleic acid (CLA) (Beaulieu et al., 2002). Ritzenthaler et al. (2001) reported that nearly $30 \%$ of the American consumer's intake of CLA was derived from beef products. CLA denotes a group of positional and geometric isomers of octadecadienoic acids with conjugated double bonds that are naturally occurring fatty acid in foods derived from ruminants. Some CLA isomers, especially cis-9, trans-11 conjugated linoleic acid (c9t11-CLA), have been identified as having anticarcinogenic (Ip et al., 1999) properties. Another CLA isomer, namely trans-10, cis-12 conjugated linoleic acid (t10c12-CLA), seems to have antiobesity properties (West et al., 2000) and might lower milk fat concentration (Baumgard et al., 2000). For these reasons, increasing the CLA content of foods may increase their nutritive and therapeutic values. Furthermore, CLA is also a component of ruminant fat that is applicable in redesigning foods because biomedical studies with animal models have demonstrated a number of beneficial health effects (Whigham et al., 2000). For years, scientists have done much research on this product of rumen biohydrogenation of polyunsaturated fatty acids (Czauderna et al., 2004; Szumacher-Strabel et al., 2004).

Some trials have been performed on how to increase the content of CLA and other beneficial fatty acids in beef (Noci et al., 2005). In addition, some attempts have also been made to modulate the fatty acid composition of milk fat through manipulating diets of dairy cows to increase CLA content in milk (Gonthier et al., 2005). Nevertheless, most studies have focused on modulating the fatty acid composition in dairy cows through dietary manipulation and some results have indicated that this approach may also increase the CLA content in beef (Dhiman et al., 1999). Enhanced levels of CLA in body fat were observed in grazing cattle (French et al., 2000).

CLA is the intermediate product of hydrogenation of $18: 2$ and 18:3 fatty acids in the rumen. The production and accretion of CLA can be increased by feeding diets high in linoleic acid to cattle (Parodi, 1999). Some trials have been conducted to investigate the effect of supplementation of vegetable oil on the CLA content of muscle in sheep (Czauderna et al., 2004). Although vegetable oils are rich in certain fatty acids that serve as precursors of CLA, they are not used as dietary supplements for beef cattle because large amounts of polyunsaturated fatty acids are toxic to rumen microorganisms and this may cause a reduction in fermentation 
rate and microbial protein yield. Processed soyabeans, rich in linoleic acid, could avoid the adverse effects mentioned above and remarkably increase the CLA content of milk from dairy cows (Chouinard et al., 2001). However, few studies using similar feeding strategies for manipulating the content of CLA and other fatty acids in beef have been conducted.

The objective of the experiment was to study the effect of roasted soyabeans with different particle size on the content of CLA and other fatty acids in the longissimus dorsi muscle, backfat and liver of beef cattle.

\section{MATERIAL AND METHODS}

\section{Treatment of soyabeans and formulation of diets}

Soyabeans were roasted for approximately $10 \mathrm{~min}$ at $240^{\circ} \mathrm{C}$ to inactivate antinutritional factors. Subsequently, the roasted soyabeans were milled to pass through a $1 \mathrm{~mm}$ sieve (finely ground) or $3 \mathrm{~mm}$ sieve (coarsely ground), respectively.

The experimental diets were formulated based on the contents of dry matter $(\mathrm{DM})$, organic matter $(\mathrm{OM})$, crude protein $(\mathrm{CP})$, ether extract $(\mathrm{EE})$, neutral detergent fibre (NDF) and fatty acids, which were determined before the experiment. The net energy (NE) was calculated according

Table 1. Ingredients and chemical composition of experimental diets

\begin{tabular}{|c|c|c|c|}
\hline \multirow{2}{*}{ Item } & \multicolumn{3}{|c|}{ Treatments } \\
\hline & 1 & 2 & 3 \\
\hline \multicolumn{4}{|l|}{ Components, g/kg DM } \\
\hline maize & 302.0 & 302.0 & 302.0 \\
\hline roasted soyabeans & 69.4 & 69.4 & 69.4 \\
\hline cotton seed hull & 159.3 & 159.3 & 159.3 \\
\hline wheat bran & 98.8 & 98.8 & 98.8 \\
\hline maize silage & 240.7 & 240.7 & 240.7 \\
\hline lucerne & 129.9 & 129.9 & 129.9 \\
\hline \multicolumn{4}{|l|}{ Nutrients, $\mathrm{g} / \mathrm{kg} D M$} \\
\hline organic matter & 942.5 & 942.5 & 942.5 \\
\hline crude protein & 125.0 & 125.0 & 125.0 \\
\hline ether extract & 192.3 & 192.3 & 192.3 \\
\hline NDF & 310.6 & 310.6 & 310.6 \\
\hline $\mathrm{NE}, \mathrm{MJ} / \mathrm{kg} \mathrm{DM}$ & 9.1 & 9.1 & 9.1 \\
\hline \multicolumn{4}{|c|}{ Content of fatty acids, $\mathrm{mg} / \mathrm{kg}$} \\
\hline C18:0 & 719.9 & 719.9 & 719.9 \\
\hline $\mathrm{C} 18: 1$ & 3838.5 & 3838.5 & 3838.5 \\
\hline $\mathrm{C} 18: 2 n-6$ & 9684.1 & 9684.1 & 9684.1 \\
\hline $\mathrm{C} 18: 3$ & 1511.8 & 1511.8 & 1511.8 \\
\hline
\end{tabular}


to Cao (2008) based on the gross energy (GE). The components and nutrients content as well as the fatty acid content of the experimental diets are shown in Table 1.

\section{Animals, feeding and management}

Fourteen 24-month-old castrated male Luxi $\times$ Limousin crossbred cattle with an average liveweight of $504.7 \pm 15.6 \mathrm{~kg}$ were used as experimental animals. The cattle were randomly assigned to 3 groups with 5,5 and 4 bulls in groups 1,2 and 3 , respectively, which were fed with diets containing $69.4 \mathrm{~g} / \mathrm{kg}$ DM finely ground soyabeans, coarsely ground soyabeans or whole soyabeans as Treatments 1,2 and 3 , respectively.

The feeding and management of the cattle were according to the "Administration Regulation on Laboratory Animals of the Beijing Municipality" (passed by the Standing Committee of the Beijing Municipal People's Congress: the Administrative Department of Beijing Municipal Science and Technology, 2002).

All cattle were given an anthelmintic (produced by Sichuan Qiquan Animal Pharmaceutical Co., Ltd., Suining, China) twice a day by mixing it into the diets, at a dosage of $25 \mathrm{~g}$ per animal for 4 successive days to destroy intestinal parasites before the experiment started. The cattle were fed with total mixed rations (including the soyabean products) in two equal meals, at 7.00 and 17.00 each day during the experimental period, respectively. Drinking water was given twice a day after feeding.

The experiment lasted 28 days. The cattle were weighed and recorded at the begining and at the end of the experiment in the morning before feeding. The feeds left were collected and weighed every day during the experimental period for the determination of daily feed intake.

\section{Slaughter trial and sampling}

At the end of the experiment, the cattle were slaughtered after an overnight fast. Tissue samples of longissimus dorsi muscle, backfat and liver were obtained. All of the samples were immediately frozen in liquid nitrogen and then transferred to a freezer at $-70^{\circ} \mathrm{C}$ until analysis.

\section{Determinations and chemical analysis}

GE of the feed samples was determined using an oxygen bomb calorimeter according to Zhang (2003). The DM, CP, EE, NDF and ash were determined according to AOAC (1990). Organic matter (OM) was calculated based on the ash content. 
The lipids of the tissue samples were freeze-dried according to the procedure used by Bligh and Dyer (1959). The longissimus dorsi muscle, backfat and liver were analysed for fatty acid composition by gas chromatography according to the method developed by Sukhija and Palmquist (1988). The extracted lipids were methylated with $0.5 \mathrm{M}$ sodium methoxide in methanol for $10 \mathrm{~min}$ at $50^{\circ} \mathrm{C}$ followed by an excess of 5\% methanolic $\mathrm{HCl}$ (acetyl chloride in methanol; Christie, 1993) at $80^{\circ} \mathrm{C}$ for $10 \mathrm{~min}$ according to the modified procedures of Sukhija and Palmquist (1988) and Kramer et al. (1997). These modifications included using hexane as a solvent instead of benzene and adding $5 \mathrm{ml}$ of $6 \% \mathrm{~K}_{2} \mathrm{CO}_{3}$ after incubation with $5 \%$ methanolic $\mathrm{HCl}$. The fatty acid methyl esters were analysed on a Hewlett Packard 6890 (Agilent Technologies, Mississauga, Ont, Canada) gas chromatograph equipped with a 6890 series autosampler, Omegawax 320 fused silica capillary column $(30 \mathrm{~m} \times 0.32 \mathrm{~mm}$ i.d. $\times 0.5 \mu \mathrm{m}$ film thickness $)$, FID detector, and integrated with Agilent Chemstation software version A. 8.03. The operating conditions were: oven temperature, $220^{\circ} \mathrm{C}$ for $10 \mathrm{~min}$ then $10^{\circ} \mathrm{C} / \mathrm{min}$ to $250^{\circ} \mathrm{C}$ and hold for $5 \mathrm{~min}$; injection port temperature, $250^{\circ} \mathrm{C}$; detector temperature, $250^{\circ} \mathrm{C} ; 1 \mu 1$ split injection volume with $\mathrm{H}_{2}$ carrier gas $(25 \mathrm{~cm} / \mathrm{s})$ and a split ratio of $50: 1$. Methyl ester standards (Nu-Chek-Prep, Elysian, MN, USA; Matreya, Pleasant Gap, PA, USA) were used to identify peaks.

\section{Calculation and statistical analysis}

$$
\text { Liveweight gain }=\left(\mathrm{W}_{2}-\mathrm{W}_{1}\right) / \mathrm{D}
$$

where: $\mathrm{W}_{1}$ - initial liveweight, $\mathrm{kg} ; \mathrm{W}_{2}$ - final liveweight, $\mathrm{kg}$; D - days of feeding.

The content of fatty acids in tissue was calculated as follows:

$$
\mathrm{P}_{\mathrm{i}}=\left(\mathrm{W}_{\mathrm{i}} / \mathrm{W}_{\mathrm{t}}\right) \times 100 \% \times 10
$$

where: $\mathrm{P}_{\mathrm{i}}$ - content of specific fatty acid, $\mathrm{g} / \mathrm{kg} ; \mathrm{W}_{\mathrm{i}}$ - weight of specific fatty acid in serum or body tissues, $\mathrm{g} ; \mathrm{W}_{\mathrm{t}}$ - total weight of fatty acids in serum or body tissues, $\mathrm{g}$.

Data were analysed using the ANOVA procedure of SPSS (Version 10.0). Differences were considered to be significant at $\mathrm{P}<0.05$ and highly significant at $\mathrm{P}<0.01$. 


\section{RESULTS}

Nutrient intake and daily gain. The results (Table 2) indicate that no significant differences in daily intakes of DM, OM, EE, CP, NDF, NE and fatty acids were found among different treatments $(\mathrm{P}<0.05)$. The results also show that there were no significant differences in initial weight, final weight or ADG among different treatments $(\mathrm{P}>0.05)$.

Table 2. Nutrient intake and liveweight gain of cattle

\begin{tabular}{|c|c|c|c|}
\hline \multirow{2}{*}{ Item } & \multicolumn{3}{|c|}{ Treatments } \\
\hline & 1 & 2 & 3 \\
\hline Initial liveweight, $\mathrm{kg}$ & $498.5 \pm 58.6$ & $505.8 \pm 70.8$ & $511.0 \pm 58.6$ \\
\hline Final liveweight, $\mathrm{kg}$ & $518.8 \pm 59.1$ & $542.7 \pm 54.3$ & $532.5 \pm 53.3$ \\
\hline Average daily gain, $\mathrm{kg}$ & $0.7 \pm 0.7$ & $1.3 \pm 0.4$ & $0.7 \pm 0.4$ \\
\hline \multicolumn{4}{|l|}{ Nutrient intake, $\mathrm{kg} / \mathrm{d}$} \\
\hline dry matter & $8.93 \pm 1.12$ & $9.42 \pm 1.21$ & $9.54 \pm 1.08$ \\
\hline organic matter & $8.42 \pm 1.10$ & $8.88 \pm 1.06$ & $8.99 \pm 0.96$ \\
\hline crude protein & $1.12 \pm 0.19$ & $1.18 \pm 0.17$ & $1.19 \pm 0.12$ \\
\hline ether extract & $1.72 \pm 0.29$ & $1.81 \pm 0.26$ & $1.84 \pm 0.18$ \\
\hline $\mathrm{NDF}$ & $2.77 \pm 0.46$ & $2.93 \pm 0.43$ & $2.96 \pm 0.30$ \\
\hline $\mathrm{NE}, \mathrm{MJ} / \mathrm{d}$ & $98.86 \pm 13.21$ & $105.08 \pm 13.36$ & $106.40 \pm 12.10$ \\
\hline \multicolumn{4}{|l|}{ Intake of fatty acids, $\mathrm{mg} / \mathrm{d}$} \\
\hline C18:0 & $6428.3 \pm 1170.0$ & $6780.3 \pm 1071.2$ & $6864.9 \pm 1082.6$ \\
\hline C18:1 & $34275.5 \pm 6515.7$ & $36152.4 \pm 5956.0$ & $36603.6 \pm 5993.1$ \\
\hline $\mathrm{C} 18: 2 n-6$ & $86473.2 \pm 10251.7$ & $91208.3 \pm 11236.3$ & $92346.7 \pm 11351.5$ \\
\hline $\mathrm{C} 18: 3$ & $13499.5 \pm 2394.9$ & $14238.7 \pm 2262.3$ & $14416.4 \pm 2150.6$ \\
\hline
\end{tabular}

Fatty acid composition in the longissimus dorsi muscle. The content of c9t11CLA in Treatment 2 was significantly higher than that in Treatment $3(\mathrm{P}<0.05)$, whereas the content of $t 10 c 12$-CLA in Treatment 2 was significantly lower than that in Treatments 1 and $3(\mathrm{P}<0.05)$. The content of total CLA in Treatment 2 tended to be higher than in Treatments 1 and 3, but the difference did not reach a significant level $(\mathrm{P}>0.05)$. The contents of $\mathrm{C} 18: 3, \mathrm{C} 18: 2 n-6$ and $\mathrm{C} 18: 0$ in Treatment 1 were significantly higher than those in Treatment $2(\mathrm{P}<0.05)$ while the content of C18:1 in Treatment 2 was higher than that in Treatment 1.

Fatty acid composition in backfat. No differences were found in the contents of c9t11-CLA, t10c12-CLA, total CLA, C18:3 and C18:2 n-6 among different treatments $(\mathrm{P}>0.05)$. The content of $\mathrm{C} 18: 1$ in Treatment 3 was significantly higher than that in Treatment $1(\mathrm{P}<0.05)$, while the content of $\mathrm{C} 18: 0$ in Treatment 1 was significantly higher than that of Treatments 2 and $3(\mathrm{P}<0.05)$. 
Fatty acid composition in liver. It was found that the contents of c9t11CLA and total CLA in Treatment 3 were significantly higher than those in Treatments 1 and $2(\mathrm{P}<0.05)$, while no difference in the concentration of t10c12-CLA among different treatments and in the content of c9t11-CLA

Table 3. Fatty acid composition in different tissues, $\mathrm{g} / \mathrm{kg}$ total fatty acids

\begin{tabular}{|c|c|c|c|}
\hline \multirow{2}{*}{ Item } & \multicolumn{3}{|c|}{ Treatments } \\
\hline & 1 & 2 & 3 \\
\hline \multicolumn{4}{|c|}{ Longissimus dorsi muscle } \\
\hline C18:0 & $145.62 \pm 10.52^{\mathrm{a}}$ & $130.16 \pm 9.63^{b}$ & $141.30 \pm 13.40^{\mathrm{ab}}$ \\
\hline C18:1 & $311.96 \pm 62.31^{\mathrm{b}}$ & $391.02 \pm 70.25^{\mathrm{a}}$ & $368.85 \pm 33.70^{\mathrm{ab}}$ \\
\hline $\mathrm{C} 18: 2 n-6$ & $49.94 \pm 12.42^{\mathrm{a}}$ & $34.98 \pm 10.60^{\mathrm{b}}$ & $30.25 \pm 4.05^{\mathrm{ab}}$ \\
\hline C18:3 & $2.88 \pm 0.80^{\mathrm{a}}$ & $2.00 \pm 0.61^{\mathrm{b}}$ & $1.95 \pm 0.60^{\mathrm{b}}$ \\
\hline c9t11-CLA & $3.52 \pm 0.59^{\mathrm{ab}}$ & $3.96 \pm 0.52^{\mathrm{a}}$ & $3.03 \pm 0.62^{b}$ \\
\hline$t 10 c 12-\mathrm{CLA}$ & $0.18 \pm 0.04^{\mathrm{a}}$ & $0.10 \pm 0.02^{\mathrm{b}}$ & $0.20 \pm 0.08^{\mathrm{a}}$ \\
\hline total CLA & $3.70 \pm 0.51$ & $4.06 \pm 0.49$ & $3.23 \pm 0.63$ \\
\hline \multicolumn{4}{|l|}{ Backfat } \\
\hline $\mathrm{C} 18: 0$ & $162.26 \pm 28.71^{\mathrm{a}}$ & $123.86 \pm 29.05^{\mathrm{b}}$ & $124.58 \pm 11.65^{\mathrm{b}}$ \\
\hline C18:1 & $405.00 \pm 26.69^{b}$ & $426.68 \pm 22.01^{\mathrm{ab}}$ & $442.43 \pm 20.14^{\mathrm{a}}$ \\
\hline $\mathrm{C} 18: 2 n-6$ & $15.30 \pm 2.64$ & $13.94 \pm 3.32$ & $12.90 \pm 3.07$ \\
\hline $\mathrm{C} 18: 3$ & $1.78 \pm 0.62$ & $1.26 \pm 0.23$ & $1.40 \pm 0.55$ \\
\hline$c 9 t 11-\mathrm{CLA}$ & $6.12 \pm 0.98$ & $5.94 \pm 1.35$ & $7.15 \pm 1.14$ \\
\hline$t 10 c 12-\mathrm{CLA}$ & $0.22 \pm 0.04$ & $0.18 \pm 0.04$ & $0.20 \pm 0.00$ \\
\hline total CLA & $6.34 \pm 1.02$ & $6.12 \pm 1.42$ & $7.35 \pm 1.14$ \\
\hline \multicolumn{4}{|l|}{ Liver } \\
\hline C18:0 & $307.80 \pm 25.39^{\mathrm{a}}$ & $302.40 \pm 27.30^{\mathrm{ab}}$ & $272.43 \pm 7.45^{\mathrm{b}}$ \\
\hline C18:1 & $111.78 \pm 17.88^{b}$ & $119.04 \pm 20.98^{\mathrm{b}}$ & $146.30 \pm 15.26^{\mathrm{a}}$ \\
\hline $\mathrm{C} 18: 2 n-6$ & $121.12 \pm 8.47$ & $124.58 \pm 19.89$ & $111.13 \pm 11.49$ \\
\hline C18:3 & $5.66 \pm 2.18$ & $5.22 \pm 1.00$ & $6.43 \pm 1.25$ \\
\hline c9t11-CLA & $3.08 \pm 0.65^{b}$ & $2.86 \pm 0.57^{b}$ & $4.58 \pm 0.28^{\mathrm{a}}$ \\
\hline$t 10 c 12-\mathrm{CLA}$ & $0.34 \pm 0.05$ & $0.28 \pm 0.04$ & $0.38 \pm 0.10$ \\
\hline total CLA & $3.42 \pm 0.71^{\mathrm{b}}$ & $3.14 \pm 0.62^{b}$ & $4.95 \pm 0.40^{\mathrm{a}}$ \\
\hline
\end{tabular}

within a row, means without a common superscript letter differ significantly $(\mathrm{P}<0.05)$; $\mathrm{C} 18: 1$ refers to the sum of $\mathrm{C} 18: 1$ isomers and $\mathrm{C} 18: 3$ refers to the sum of all the positional isomers of $\mathrm{C} 18: 3$

and total CLA were found between Treatments 1 and $2(\mathrm{P}>0.05)$. No differences were found in the contents of $\mathrm{C} 18: 3$ and $\mathrm{C} 18: 2$ n- 6 among different treatments $(\mathrm{P}>0.05)$. The content of $\mathrm{C} 18: 1$ in Treatment 3 was significantly higher than that in Treatments 1 and $2(\mathrm{P}<0.05)$ while the concentration of $\mathrm{C} 18: 0$ in Treatment 1 was higher than that in Treatment $3(\mathrm{P}<0.05)$, but no difference was found between Treatments 1 and $2(\mathrm{P}>0.05)$. 


\section{DISCUSSION}

The average daily gain (ADG) of Treatment 2 tended to be higher than that in Treatments 1 and 3 but the difference did not reach the level of significance. The reason for the results could be that finely ground soyabeans might have some inhibitive effect on rumen microorganisms since soyabeans are rich in fatty acids, while whole soyabeans might not be effectively digested by cattle, therefore resulting in lower ADG. The feeding experiment lasted only 28 days and this might be an important reason that the difference between different treatments did not reach significance. A longer feeding experiment may be necessary to obtain significant results.

It can be seen in Tables 1 and 2 that the dietary content and daily intake of C18:2 n-6 and C18:3 were very high, whereas the contents of C18:2 n-6 and C18:3 were relatively low. The results indicate that a large proportion of unsaturated fatty acids was transformed to C18:1 or C18:0 in rumen biohydrogenation or in tissue metabolism. Previous studies have demonstrated clearly that little doublebonded unsaturated fatty acids such as CLA flow out of the rumen, while the outflow of trans-11 C18:1 is 20 times greater than that of CLA in steers fed typical finishing diets (Sackmann et al., 2003). The results in the present experiment are in agreement with those mentioned above.

CLA is an intermediate product in the process of rumen biohydrogenation of unsaturated fatty acids (Parodi, 1999), while endogenous synthesis of CLA in tissues has been shown to account for more than two thirds of $c 9$ t11-CLA in milk fat of dairy cows (Corl et al., 2001). The synthesis of CLA in biohydrogenation is influenced by available precursors such as linoleic acid. Soyabeans contain a high level of fatty acids, especially linoleic acid, and therefore should improve CLA synthesis in rumen biohydrogenation. Finely ground soyabeans would increase the interface between rumen microorganisms and soyabeans, making more precursors available for the synthesis of CLA, whereas unsaturated fatty acids would inhibit the activity of rumen microorganisms, resulting in less CLA synthesis. The results in the present experiment indicate that total CLA in longissimus dorsi muscle, backfat and liver in Treatment 1 was between that of Treatments 2 and 3. Rumen bacteria involved in biohydrogenation can be divided into groups A and B (Kemp et al., 1984), in which group A bacteria are involved in reactions leading to trans-11 C18:1 formation and group B bacteria are predominantly involved in catalyzing the final step that converts trans-11 C18:1 to stearic acid (Harfoot and Hazlewood, 1988). The particle size of soyabeans might have an important influence on rumen $\mathrm{pH}$ or passage rate of rumen digesta, which might consecutively alter the proportion and population of groups A and B bacteria, and in turn affect CLA synthesis.

Compared with the finely ground soyabeans, the whole soyabeans would have a smaller interface with rumen microorganisms. On one hand, this would 
decrease the available precursors for the synthesis of CLA. On the other hand, whole soyabeans would increase by-pass unsaturated fatty acids such as oleic acid and linoleic acid, which would in turn be utilized for CLA synthesis in tissues, therefore resulting in higher total CLA in Treatment 3 than that of Treatments 1 and 2.

The results in the present experiment show that the content of c9t11-CLA was higher than that of $t 10 c 12$-CLA in all tissues. There could be two reasons for this. One could be that in rumen biohydrogenation of unsaturated fatty acids, the $t 11$ pathway (synthesis of $c 9 t 11$-CLA) is more effective than the $t 10$ pathway (synthesis of $t 10 c 12$-CLA). Another could be that $\Delta 9$-desaturase is relatively active in the adipose tissue of steers (Cameron et al., 1994) and mainly improves c9t11-CLA synthesis from trans-11 C18:1.

The results also showed that the total CLA of backfat was higher than that of longissimus dorsi muscle and liver, indicating that the adipose tissue was the major site for the synthesis of CLA compared with longissimus dorsi muscle and liver. The results might have been resulted from higher $\Delta 9$-desaturase activity in adipose tissue that improved c9t11-CLA synthesis from other unsaturated fatty acids.

\section{CONCLUSIONS}

It is concluded that the diet containing $69.4 \mathrm{~g} / \mathrm{kg}$ DM roasted whole soyabeans tended to increase the total conjugated linoleic acid contents in backfat and liver of beef cattle. Longer feeding experiments are necessary to validate the effect.

\section{REFERENCES}

AOAC, 1990. Association of Official Analytical Chemists, Official Methods of Analysis. $14^{\text {th }}$ Edition. Washington, DC

Baumgard L.H., Corl B.A., Dwyer D.A., Saebo A., Bauman D.E., 2000. Identification of the CLA isomer that inhibits milk fat synthesis. Amer. J. Physiol.-Regul. Integr. C 278, 179-184

Beaulieu A.D., Drackley J.K., Merchen N.R., 2002. Concentrations of conjugated linoleic acid (cis-9, trans-11-octadecadienoic acid) are not increased in tissue lipids of cattle fed a highconcentrate diet supplemented with soybean oil. J. Anim. Sci. 80, 847-861

Bligh E.G., Dyer W.J., 1959. A rapid method of total lipid extraction and purification. Can. J. Biochem. Physiol. 37, 911-917

Cameron P.J., Rogers M., Oman J., May S.G., Lunt D.K., Smith S. B., 1994. Stearoyl coenzyme A desaturase activity and mRNA levels are not different in subcutaneous adipose tissue from Angus and American Wagyu steers. J. Anim. Sci. 72, 2624-2628

Cao N.X., 2008. Beef Feed and New Feeding Technique. China Agricultural Scientech Press, Beijing (China) 
Chouinard P.Y., Corneau L., Butler W.R., Chilliard Y., Drackly J.K., Bauman D.E., 2001. Effect of dietary lipid source on conjugated linoleic acid concentrations in milk fat. J. Dairy. Sci. 84, 680-690

Christie W.W., 1993. Preparation of lipid extracts from tissues. In: Advances in Lipid Methodology. Oily Press Ltd., Alloway (UK), pp. 195-213

Corl B.A., Baumgard H., Dwyer D.A., Griinari J.M., Phillips B.S., Bauman D.E., 2001. The role of D9-desaturase in the production of cis-9, trans-11 CLA. J. Nutr. Biochem. 12, 622-630

Czauderna M., Kowalczyk J., Niedźwiedzka K.M., Wąsowska I., Pająk J.J., 2004. The effect of selenium and linseed oil on growth of sheep and content of selected fatty acids in M. longissimus dorsi. J. Anim. Feed Sci. 13, Suppl. 1, 303-306

Czauderna M., Kowalczyk J., Niedźwiedzka K.M., Wąsowska I., Pająk J.J., Bulska E., Ruszczyńska A., 2004. The effect of linseed oil and selenium on the content of fatty acids and some elements in the liver and selected tissues of sheep, J. Anim. Feed Sci. 13, Suppl. 2, 103-106

Dhiman T.T., Helmink E.D., McMahon D.J., Fife R.L., Pariza M.W., 1999. Conjugated linoleic acid content of milk and cheese from cows fed extruded oilseeds. J. Dairy. Sci. 82, 412-419

French P., Stanton C., Lawless F., O'Riordan E.G., Monahan F.J., Caffrey P.J., Moloney A.P., 2000. Fatty acid composition, including conjugated linoleic acid, of intramuscular fat from steers offered grazed grass, grass silage, or concentrate-based diets. J. Anim. Sci. 78, 2849-2855

Gonthier G., Mustafa A.F., Ouellet D.R., Chouinard P.Y., Berthiaume R., Petit H.V., 2005. Feeding micronized and extruded flaxseed to diary cows: effects on blood parameters and milk fatty acid composition. J. Dairy Sci. 88, 748-756

Harfoot C.G., Hazlewood G.P., 1988. Lipid metabolism in the rumen. In: P.N. Hobson (Editor). The Rumen Microbial Ecosystem. Elsevier, Amsterdam, pp. 285-322

Ip C., Banni S., Angioni E., Carta G., McGinley J., Thompson H. J., Barbano D., Bauman D., 1999. Conjugated linoleic acid-enriched butter fat alters mammary gland morphogenesis and reduces cancer risk in rats. J. Nutr. 129, 2135-2142

Kemp P., Lander D.J., Holman R.T., 1984. The hydrogenation of the series of methylene-interrupted cis, cis-octadecadienoic acids by pure cultures of six rumen bacteria. Brit. J. Nutr. 52, 171-177

Kramer J.K.G., Fellner B., Dugan M., Sauer F., Mossoba M., Yurawecz M., 1997. Evaluating acid and base catalysts in the methylation of milk and rumen fatty acids with special emphasis on conjugated dienes and total trans fatty acids. Lipids 32, 1219-1228

Noci F., O’Kiely P., Monahan F.J., Stanton C., Moloney A.P., 2005. Conjugated linoleic acid concentration in M. Longissimus dorsi from heifers offered sunflower oil-based concentrates and conserved forages. Meat Sci. 69, 509-518

Parodi P.W., 1999. Conjugated linoleic acid and other anticarcinogenic agents of bovine milk fat. J. Dairy Sci. 82, 1339-1349

Ritzenthaler K.L., McGuire M.K., Falen R., Shultz T.D., Dasgupta N., McGuire M.A., 2001. Estimation of conjugated linoleic acid intake by written dietary assessment methodologies underestimates actual intake evaluated by food duplicate methodology. J. Nutr. 131, 1548-1554

Sackmann J.R., Duckett S.K., Gillis M.H., Realini C.E., Parks A.H., Eggelston R.B., 2003. Effects of forage and sunflower oil levels on ruminal biohydrogenation of fatty acids and conjugated linoleic acid formation in beef steers fed finishing diets. J. Anim. Sci. 81, 3174-3181

Sukhija P.S., Palmquist D.L., 1988. Rapid method for determination of total fatty acid content and composition of feedstuffs and feces. J. Agr. Food Chem. 36, 1202-1206

Szumacher-Strabel M., Potkański A., Cieślak A., Kowalczyk J., Czauderna M., 2004. Effect of adding fat to the diet for lambs on the fatty acid profile of intramuscular, perirenal and subcutaneous fat. J. Anim. Feed Sci. 13, Suppl. 1, 355-358 
West D.B., Blohm F.Y., Truett A.A., DeLany J.P., 2000. Conjugated linoleic acid persistently increases total energy expenditure in $\mathrm{AKR} / \mathrm{J}$ mice without increasing uncoupling protein gene expression. J. Nutr. 130, 2471-2477

Whigham L.D., Cook M.E., Atkinson R.L., 2000. Conjugated linoleic acid: implications for human health. Pharmaceut. Res. 42, 503-510

Zhang L.Y., 2003. Testing Technique for Feed Analysis and Feed Quality. China Agricultural University Press, Beijing (China) 